\title{
The effects of government construction projects abandonment: stakeholders' perspective
}

\section{Introduction}

This study investigates the effects of government construction projects abandonment on stakeholders in an emerging economy by focussing on Ghana. Government policies are often translated into programmes and projects (Goodman and Love, 1980). One area in which these programmes and projects are implemented is within the construction sector. The construction industry of every country drives economic growth (Sambasivan and Soon 2007; Sweis et al., 2008; Shehu et al., 2014; Pero et al., 2015; Sinesilassie et al., 2017). Therefore, the importance of project management within the industry cannot be overemphasised. However, research indicates that some of these projects have failed (Frimpong et al., 2003; Sambasivan and Soon 2007; Sweis et al., 2008; Shehu et al., 2014). As a result, extant literature has been devoted to discussions on these failed construction projects; nevertheless, they have mainly been discussed in relation to factors (causes) that lead to failure. Specifically, the construction project management literature has been devoted to factors (causes) of cost overrun (Kaming et al., 1997; Frimpong et al., 2003; Muya et al., 2013), schedule delays (Kaming et al., 1997; AlKhalil and Al-Ghafly; 1999; Faridi and El-Sayegh, 2006; Khoshgoftar et al., 2010; Al-Kharashi and Skimore, 2009; Muya et al., 2013; Lindhard and Wandahl, 2014; Amoatey., 2015; Mishmish and El-Sayegh, 2016) and requirement deviation (Muya et al., 2013; Damoah and Akwei, 2017). However, this study moves away from these failure criteria by proposing an empirical study that focuses on construction project failure through abandonment. This study has a wider scope than the research by Abdullah et al. (2014) that investigated the effects of only housing projects abandonment.

Further, there are few studies that have investigated the effects of construction projects failure; and these have mainly been discussed in relation to the effects on the completion of the projects (Aibinu and Jagboro, 2002; Sambasivan and Soon, 2007; Efenudu, 2010; Pourrostam 
and Ismail, 2011; Amoatey et al., 2015). At present, the studies that have assessed the effects in relation to stakeholders associated with the construction projects are rare and that includes the work of Efenudu (2010) and Amoatey et al. (2015). Nevertheless, they took failure from multiple failure criteria (generic) in their assessment. Moreover, they did not discuss how failed projects affect the stakeholders - they only mentioned the type of effects. This study extends construction projects management research? by investigating the effects on stakeholders associated with government construction projects abandonment and how these stakeholders are affected.

This study focus on the Ghanaian context due to the recent economic developments which was propelled by the country's discovery and exploration of oil in commercial quantities in 2010 (Ahadzie, 2009). This development drove the country into high level of economic growth - with $20 \%$ growth rate, making the country number in the world economic growth (Economy Watch, 2011). This has necessitated the need to embark on infrastructural development projects to sustain the development, hence, construction projects (Republic Ghana Budget, 2012, 2015). The Ghanaian construction sector contributes to the socioeconomic development (Amponsah, 2010, Amoatey et al., 2015). The industry is multi-faceted and it is spread across all sectors of the economy (Ofori, 2012). It contributes $\$ 3.8$ bn to the gross domestic product (GDP) - representing 12.7\% of the total GDP (Ghana Statistical Service, 2015). The industry is huge and considered as the backbone for the rest of the other sectors to thrive (Amponsah, 2010; Amoatey et al., 2015). It provides a significant number of job offerings for the populace, through the creation of direct and indirect job opportunities (Ahadzie, 2009; Amoatey et al., 2015); and as such successive Ghanaian governments have made conscious efforts to improve the sector. Despite the conscious efforts put in place by the government in the implementation of such projects through the yearly budget (Republic of Ghana Budget, 2012, 2015); many Ghanaians have doubts over the success of these projects 
(Bawumia, 2015, 2016). The doubt is premised on their experience with similar projects in the past; where projects failed through abandonment. Typical examples include the abandonment of many Ghanaian government projects in the immediate post-colonial era where many state policies were implemented through the ideology of industrialisation (Jeffries, 1982; Aryeetey and Jane, 2000; Klutse, 2009; Damoah and Akwei, 2017). Therefore, the need to investigate the effects that these abandoned construction projects may have on stakeholders associated with such projects cannot be overemphasised. The key question is: what are the effects of abandonments on stakeholders associated with such projects and how are these stakeholders affected?

Moreover, the Ghanaian government construction projects context is important due to the essential role that these projects play in the national growth and development; and the numerous stakeholders associated with these projects. Unlike the private sector construction projects, the Ghanaian government construction projects have many stakeholders with varying interest and such failure may have significant effects on these stakeholders - especially the general populace. Like many developing countries, Ghanaian government constructions projects are stakeholder-based and as such, the effects that failure may bring on them cannot be overemphasised and this calls for investigation. This study, therefore, propose that failure of these projects may have significant effects on these stakeholders.

In addition, this study focuses on government construction projects abandonment in an emerging economy due to the political nature in the implementation of government projects and programmes, and the administration of the public sector (Damoah and Akwei, 2017).

Furthermore, this research focuses on Ghanaian government construction projects abandonment because; the country typifies an emerging economy where infrastructural development projects have become the pinnacle of development, hence, numerous implementation of government constructions projects (Ofori, 2012; Amoatey et al., 2015; 
Damoah, 2015; Damoah et al., 2015; Damoah and Akwei, 2017). Literature suggest that developed economies developed through the implementation of infrastructure development projects, hence, construction projects - these projects serves as the foundation for the rest of the economy to flourish (Sambasivan and Soon 2007; Sweis et al., 2008; Ofori, 2012; Shehu et al., 2014; Pero et al. 2015; Amoatey et al., 2015); hence, failure through abandonment might have devastation effects on the citizens and the direction of development.

Using sequential data collection approach through focused group discussions, questionnaire and an in-depth semi-structured interview, twenty-six (26) effects of construction projects abandonment on stakeholders are identified. The top ten most important effects are unemployment, bad image for the government, government sector underdevelopment, stunted economic growth, financial institutions lose confidence in the state, discourages investment, loss of revenue by state, pollution, loss of properties and loss of revenue by the citizens. The effects were grouped into four main themes and the most important effects are the economic, social, political and psychological respectively. The findings also suggest that some of these effects are direct whilst others are indirect; and they are cyclical in nature.

This research offers two major contributions to both theory and practice. Theoretically, this study has espoused effects of government construction projects abandonment on stakeholders associated with such projects by assessing how stakeholders are affected. Practically, practitioners and policy makers of Ghana and other developing countries with similar contextual dynamics would be able to use findings as a guide during the implementation of government construction projects in order to minimise the effects of abandonment on stakeholders.

The remainder of this research is presented as follows: section two reviews the literature relating to the study. Section three discusses the research method used whilst section four 
presents the results and discussion of the study. Section five concludes the study by highlighting the main findings.

\section{Theoretical Framework}

\subsection{Stakeholders Theory and Government Projects}

Stakeholder theory was first proposed by Freeman (1984) in his book Strategic Management: A Stakeholder Approach. However, other authors such as Fontaine et al. (2006) credit the theory to an internal memo report of the Stanford Research Institute (SRI) in 1963 that defines stakeholders as those groups without whose support the organization would cease to exist. Freeman defines stakeholder as any organisation or individual who can affect or is affected by the achievement of the organisation's objectives. The foundations of stakeholder theory claim that firms have 'an ethical duty to stakeholders above and beyond what is required by law and, in particular, ethical duties that require the firm to operate in ways that will foreseeably reduce long-term profits' (Heath and Norman, 2004, p.249).

Despite the extensive use of the theory in many subject areas since the work of Freeman in 1984, the theory was rarely applied in project management. However, in the past two decades, researchers have become more aware of the importance of stakeholders in the management of projects and as such, there is the resurgent application of the theory in both the academic and practical fields of project management. For instance, the work of Saebo et al. (2011) and Axelsson et al. (2012) are great examples of how the theory has been applied in the past decade.

Further, the theory was first applied in the private sector but recently, researchers are paying attention to the use of the theory in the public sector due to the awareness of the numerous stakeholders associated with government projects (e.g. Elias, 2002; Pan, 2005; Pan and Pan, 2006; Flak and Nordheim, 2006; Sæbø, et al., 2011). For example, Elias et al. (2002) 
used the stakeholder framework to highlight Research and Development (R \& D) project management in New Zealand. Similarly, in an analysis of stakeholder impact on construction project management, Olander (2007) applied the theory. In line with these previous studies, this study adopts the stakeholder theory as the basis for identifying the various stakeholders who could be affected by the Ghanaian government construction projects abandonment as presented in the next sub-section.

\subsubsection{Stakeholders Associated with Ghanaian government projects}

Many stakeholder identification techniques have been offered by different authors, however, a consensus has not been reached. For instance, Alexander and Stevens (2002) prescribe a practical guidance for the identification through the performing organisations' managers - who would list all the various parties involved in the project implementation process. The process is carried out on the organisational hierarchical structure. Similarly, Robertson (2000) and Alexander and Robertson (2004) provide a model that describes stakeholder diversity with the use of 'the onion model' and locate each of the stakeholder types in one of the 'onion levels' (rings). They assert that each stakeholder should be identified within the rings found in the 'onion'. This approach does not take into consideration the project context though.

Even though these frameworks offer practical approaches to stakeholder identification, they have been criticised for being more of practical approach than a theoretical framework (Ballejos and Montagna, 2008). Drawing on this criticism, Mok et al. (2015) argue that the foundation for stakeholder identification and prioritisation is not strong due to the limited cognition of project managers and incomplete stakeholder boundaries and therefore, it's

difficult to have a definitive theory that may be applicable to all projects. In spite of the criticisms leveled against these approaches, the theory proposed by Mitchell, Agle, and Wood (1997) has been applied in different projects context by different researchers. Notable 
applications of the theory in project management research are the work of Elias et al. (2002), Pan (2005) and Olander (2007).

Mitchell et al. (1997) proposed the stakeholder salience; which comprises of three main criteria - stakeholders' power (ability to influence the firm), legitimacy (relationship between stakeholder and the firm based on contracts and legal title), and urgency (the degree to which managerial delay in attending to the claim is unacceptable to stakeholders). They argue that to qualify to be classified as a stakeholder, one must possess at least one of the salience. However, they argue that a stakeholder who possesses all the three attributes tends to receive more attention from managers. On the basis of the three attributes, they categorised stakeholders into seven (7) and are: (1) Dormant stakeholders - possess the power to impose their will but do not have any legitimate relationship or urgent claim, and their power remains unused; (2) Discretionary stakeholders - possess legitimacy but have no power or urgent claims and as such there is no absolute pressure for management to engage them in an active relationship; however, they may decide to do so when necessary; (3) Demanding stakeholders - have an urgent claim but have no power or legitimate relationship; this is bothersome but does not warrant more than passing management attention; (4) Dominant stakeholders - have power and legitimacy, hence, their actions may be a bother to management; (5) Dangerous stakeholders - possess power and urgency but have no legitimacy; they are coercive and have the possibility of being violent, hence, 'dangerous'; (6) Dependent stakeholders - possess legitimacy and urgency but have no power, therefore they depend on others for power to carry on their will; and (7) Definitive stakeholders - have power and legitimacy; they are often part of the organisation's dominant coalition and therefore, if their claim(s) is urgent, management must give priority to their claims.

In order to identify the stakeholders who would be affected by Ghanaian government construction projects abandonment, so that an examination could be carried out on how they 
are affected, the seven categorisations are adapted for this purpose. The table 1 below presents all the categorisation.

\begin{tabular}{|c|c|c|c|c|c|}
\hline Stakeholder & Stakeholders & \multicolumn{3}{|c|}{ Attributes of Salience } & \multirow{2}{*}{$\begin{array}{c}\text { Sub-classification } \\
\text { (type) }\end{array}$} \\
\hline \multirow{4}{*}{$\begin{array}{l}\text { Latent } \\
\text { stakeholder (1 } \\
\text { attributes) } \\
\text { Low salience }\end{array}$} & & Power & Legitimacy & Urgency & \\
\hline & & $\mathrm{X}$ & & & Dormant \\
\hline & & & $\mathrm{X}$ & & Discretionary \\
\hline & Media & & & $X$ & Demanding \\
\hline \multirow{6}{*}{$\begin{array}{l}\text { Expectant } \\
\text { stakeholders }(2 \\
\text { attributes) } \\
\text { Moderate } \\
\text { salience }\end{array}$} & $\begin{array}{l}\text { Donor agencies } \\
\text { and countries }\end{array}$ & $\mathrm{X}$ & $\mathrm{X}$ & & Dominant \\
\hline & $\begin{array}{l}\text { Financial } \\
\text { institutions }\end{array}$ & $\mathrm{X}$ & $X$ & & Dominant \\
\hline & $\begin{array}{l}\text { Local } \\
\text { communities }\end{array}$ & $\mathrm{X}$ & & $\mathrm{X}$ & Dangerous \\
\hline & Contractors & & $\mathrm{X}$ & $X$ & Dependent \\
\hline & Local businesses & & $\mathrm{X}$ & $\mathrm{X}$ & Dependent \\
\hline & $\begin{array}{l}\text { General } \\
\text { public/citizens }\end{array}$ & & $\mathrm{X}$ & $\mathrm{X}$ & Dependent \\
\hline \multirow{4}{*}{$\begin{array}{l}\text { Definitive } \\
\text { stakeholders (3 } \\
\text { attributes) } \\
\text { Definitive } \\
\text { salience }\end{array}$} & & & & & \\
\hline & $\begin{array}{l}\text { Government } \\
\text { (Client) }\end{array}$ & $\mathrm{X}$ & $\mathrm{X}$ & $\mathrm{X}$ & Definitive \\
\hline & $\begin{array}{l}\text { Project } \\
\text { management } \\
\text { Practitioners } \\
\end{array}$ & $\mathrm{X}$ & $\mathrm{X}$ & $\mathrm{X}$ & $\mathrm{X}$ \\
\hline & $\begin{array}{l}\text { Consultants } \\
\text { (auditors) }\end{array}$ & $\mathrm{X}$ & $\mathrm{X}$ & $\mathrm{X}$ & $\mathrm{X}$ \\
\hline
\end{tabular}

Table 1. Stakeholder identification matrix for Ghanaian government construction

From the table above, the latent stakeholder group possess only one attribute and have low salience. There are no dormant stakeholders who possess the power to impose their will but, do not have any legitimate relationship or urgent claim and discretionary stakeholders who possess legitimacy but, have no power or urgent claims. The only demanding stakeholder identified is the media. The media have urgent claims but have no power or legitimate relationship and therefore, needs minimal attention and therefore are not focused in this study.

The second is the expectant group - they possess two attributes; power and legitimacy, and they include donor agencies/countries and financial institutions. These are dominant stakeholders whose actions would have a significant impact on Ghanaian government construction projects implementation and the decision to abandon such projects. They provide financial and material resources needed for the execution of the projects and therefore, 
abandonment would have significant effects on them. The local communities are the dangerous stakeholders who possess power and urgency and therefore failure would affect them greatly. The general public, local businesses/suppliers, and contractors are dependent stakeholders who possess legitimacy and urgency but, have no power. Further, they are also the main beneficiaries of government projects and therefore they must be important stakeholder who may be affected by abandonment.

Lastly, the definitive group possesses all of the three attributes. In the case of Ghanaian government construction projects, the government, project manager practitioners, and consultants are identified. They are normally part of the government's dominant coalition in the project delivery, and therefore, an abandonment of Ghanaian construction projects may affect them greatly.

\section{Literature Review}

\subsection{Previous Research on Effects of Construction Projects Failure}

Mukuka et al. (2015) assessed the most important effects of construction projects schedule overruns in South Africa, using Gauteng Province as a case study. Using a questionnaire sample survey of 146 from construction professionals, seventeen (17) effects were identified. They include (in descending order): extension of time, cost overruns, loss of profits, disputes, poor quality of work, stress to the clients, acceleration losses, bad reputation with contraction team, claims, delays in getting profits by the client, creates stress on the contractors, delaying the client to repay back the bank loans, bad reputation with client, termination of contracts, arbitration, bankruptcy of the client, idling resources, litigation, total abandonment and loss of skilled employees.

In an assessment of the causes and effects of abandoned development projects in real property values in Nigeria, Woka and Miebaka (2014) identified eight (8) effects and are: 
values reduction; income receivable; disappointments on the owner and the populace; increases the negative effects on environment; it reduces the motivation to attract investment; waste of financial and material resources; reduction in employment opportunity and other sectors affected ; and deprivation of government tax revenue. In Malaysia housing projects abandonment, the main effects are that house buyers pay for houses before they are handed to them in a later date, which means that time value for money would be against the buyers (Abdullah at al., 2014).

In Spanish coast, urbanisation projects abandonment affects the environment in the form of visual, landscape modification, biodiversity decrease and pollution (Carrero et al., 2009). Carrero et al. (2009) further identified socio-economic effects as unemployment, conflicts between public administration and private sector, loss of economic value of the area, marginalisation of population and transfer of cost between private and public sector. However, the specific socio-economic effects were not stated. Ayodele and Alabi (2011) identified wasted resources and loss of tax revenue by the government and other stakeholders associated with such projects as the main effects of developmental construction projects abandonment in Nigeria. Similarly, Ngacho and Das (2014) evaluated the performance of construction projects in Kenya and identified economic and social effects as the main effects on the general populace - though, they did not identify the specific economic and social effects.

In real property projects abandonment, Efenudu (2010) identified lowering of properties value within the neighbourhood. Sambasivan and Soon (2007) identified the following effects: time overrun, cost overrun, disputes, arbitration, litigation and total abandonment. The failure criteria assessed by them were in the delays failure criteria. Similarly, Amoatey et al. (2015) identified the effects of delays in construction projects failure in Ghana as cost overrun, time overrun, litigation, lack of continuity by client and arbitration. 
To date and to the extant of literature examined, the research observes that even though there are few researches that have been devoted to the effects of projects failure, they have not been discussed from the stakeholders' perspective. Thus, the identified effects are more generic rather than from stakeholders' position. They did not also discuss how stakeholders may be affected. It is proposed that: since government projects are stakeholder-based and the main purpose is often to add soft or hard benefits to the citizens in order to improve their life (Ahsan and Gunawan, 2010), failure in the form of abandonment would have potential effects on these stakeholders associated with such projects.

\section{Methodology}

\subsection{Population}

Three groups of the audience were targeted to provide their perception of the effects of Ghanaian government construction projects abandonment on stakeholders. These consisted of project management practitioners, contractors, and clients (Government officials leading/coordinating projects). The population targeted for this study were drawn from professional members of the Ghana Business Directory; Ghana Institute of Engineers, Ghana Association of Managers; Association of Building and Civil Engineering Contractors of Ghana and Chartered Institute of Project Management - Ghana; Ministries, Departments and Agencies (MDAs) that are involved in constructions projects - Ministry of Roads and Highways; Ministry of Water Resource and Housing; Department of Feeder Roads; Department of Urban Roads and other government representatives on various projects at the Municipal and District Assemblies.

\subsection{Research Approach}




\section{An initial literature review was conducted to identify possible effects of construction projects}

failure on stakeholders. An initial systematic review was conducted in order to provide evidence for synthesis (Tranfield et al., 2003). This was done following the procedure suggested Khan et al. (2003), Ke et al. (2009) and Lu et al. (2014). The first step in the process is to the Framing Questions for a Review (Khan et al., 2003). Accordingly, this review of literature in this study begin by framing the main research question. Search keywords are required to be set in order to meet the requirements of research (Ke et al., 2009). According to Lu et al. (2014), in order to ensure search range of the review, plural forms of search keywords are advisable. In step two is the selection of sources of data; comprehensive and extensive search from relevant database and journals is required (Khan et al., 2003). Hence, in order to capture a lot of relevant citations, journals in the appropriate field of study need to be identified and selected for the review (Lu et al., 2014). To do so in this study, ScienceDirect was used as the main search engine. However, having gone through the list, all the construction management; operations and production management and Project management Journals were not on the ScienceDirect. Therefore, the ABS Journal Rankings was used as a guide to select specific journals that publish Construction management papers. The last thing that done was to use google scholar - this was used with the assumption that there may be some Ph.D. theses and other industry practitioners report that might contain information about the topic. Step three is to Perform Preliminary Search involving preliminary search by using the search keywords within the defined specific domain of Titles, Keywords, and Abstract. These search keywords are inserted and entered into the identified and selected journal databases (Ke et al., 2009; Lu et al., 2014). To do so, a general search on construction projects failure and factors and/or causes of construction projects failure. Words and phrases such as construction projects abandonment; construction abandonment; construction projects failure; government construction projects abandonment/failure; why construction projects abandonment was then 
used. This was done to have general knowledge about construction projects abandonment and factors that may lead to abandonment. The search needs to be rigorous, without any language restrictions, and subject to flow from the research questions as priori (Khan et al., 2003). Lu et al. (2014) and Ke et al. (2009) also suggest that at this step, the search should be using to confine the parameter search to in order to ensure consistency. Step 4 is: Assessing the Quality of Studies to ensure academic rigor (Khan et al., 2003). This implies that acquired articles for analysis and synthesize should be subjected to assessed qualities. At this stage of the literature review process, the search words and phrases were then narrowed down to the effects of construction projects abandonment and/or failure -which are more specific to the research topic. Step six is when the evidence is summarised; thus, when the detailed review is done through analysis and synthesis of the literature identified that are relevant to the study (Lu et al., 2014). At this stage, the literature could be tabulated and put into themes. Accordingly, this was tubulated based on similarities in the findings (Khan et al., 2003. Lastly, step six is the Interpreting the Findings; at this stage, the data are synthesized and interpreted from the tabulation and then recommendations made. using the evidence of strength and weaknesses (Khan et al., 2003). In this study, this was not done as it is not exclusively systematic literature paper; and therefore, what was done at this stage was to group the findings in order to identify the research gaps, that calls for this study and also the various variables that are used for the development of the questionnaire. The Preliminary findings showed that much has not been done in the research and therefore a second approach was adopted through focussed group discussions to explore the possible effects.

Further, this exploratory data collection was conducted to explore the possible effects within the local context. People with a minimum of ten years of projects management experience were targeted. The reason was to solicit data from only those with rich knowledge about the phenomenon under investigation (Saunders et al., 2012). This was done through 
direct contact with participants, LinkedIn profile, profiles on company websites and published work. Three separate discussions were made for each of the three sets of participants. An insight from a pilot discussion showed that the most appropriate way to do the discussion was to separate the different sets of participants. Two reasons informed this decision - one, it was difficult to put all the categories together; and two, these three sets of categories of participants have difficulty in understanding each other with respect to the terms and languages used. This is also informed by the researcher's previous knowledge about how they talk during interviews. In all 12 participants (4 each from each participant group) were selected for this exercise.

The results from the focused-group discussions were compared with the literature review in order to develop the questionnaire. This was to ensure that effects variables to be used in the questionnaire are not repeated. After auditing, twenty-six effects were left for the questionnaire design. Using a five-point Likert Scale, where 1= Strongly Disagree, 2= Disagree, $3=$ Neutral, 4= Agree, 5= Strongly Agree; the twenty-six variables were put on the scale for respondents to rank them.

PMP and Contractors sample size was determined by adapting Yamane's formula (Israel, 1992). As at the time of this study, 722 active registered professionals who worked for active and well-known companies were available for the research. The steps below were then followed:

1. Number of Active Registered Company $=722(\mathrm{~N}=722)$. At an acceptable $95 \%$ level of confidence, the statistical $\mathrm{z}$ value of $2(\mathrm{z}=2)$, and with an error limit of $10 \%$.

Adapting the formula:

$$
\begin{aligned}
& n=\frac{N}{1+N e^{2}}=\frac{722}{1+722(0.01)^{2}}=\frac{722}{8.22} \\
& n=\frac{722}{8, .22}=87
\end{aligned}
$$


Where,

$\mathrm{n}=$ required response

$\mathrm{e}^{2}=$ limit of error

$\mathrm{N}=$ sample size

2. Even though the 87 were the required sample size, this was increased to 300 in order to strengthen the validity of the data. This was then distributed to individual PMP and contractors in these companies through simple random approach. 173 (contractors=69; $\mathrm{PMP}=104$ ) usable questionnaires were received - which is above Yamane's required response threshold (Israel, 1992).

For the Clients (GO), it was difficult to know the exact number and therefore all government officials working in MDAs were targeted through snowballing approach. Further, the researcher has an in-depth knowledge about the difficulty in obtaining data from government officials who are appointed mainly to head these projects on the basis of political affiliation. It was therefore assumed that the response rate would be low - so targeting few would affect the response rate greatly. In the end, 200 questionnaires were distributed to the respondents in person and through emails. 57 usable questionnaires were received. In total, 500 questionnaires were distributed and 230 usable were returned and used for the analysis. The full respondents' information is presented in Appendix A.

Following from the questionnaire survey and analysis, an in-depth semi-structured interview was conducted in order to assess how stakeholders are affected by Ghanaian government construction projects abandonment. Sixteen (16) participants (PMP =7; Contractors $=4$; Client $(\mathrm{GO})=5$ ) were selected using purposive sampling technique. The full respondents' information is presented in Appendix B. 
The number was not pre-determined prior to the commencement of the interview but was reached when the data reached its saturated point (Morse, 1995, 2000; Hill et al., 2005; Guest, 2006; Silverman, 2013). These were selected from those who took part in the questionnaire and were ready to provide further explanation of these effects and how they affect the stakeholders. Interviews were conducted in English by one of the researchers and lasted between thirty and forty-five minutes. They were held in participants' homes, offices, sites, and Skype. Interviews were audio recorded and notes taken at the permission of the interviewee. These were then transcribed and uploaded into the NVivo10 after each interview. The data were further reduced by selecting, focusing and condensing. This was then analysed using the thematic analysis techniques by using line-by-line approach to identify themes. based on the themes used in the questionnaire data analysis, and in vivo codes were also identified during the line by line coding process. After the line-by-line coding process, content and crosscase analysis were conducted, and sentences were coded to the themes to explain the themes. Axial coding was also conducted to identify and explain the relationship between the effects and the stakeholders who are affected by Ghanaian government construction projects abandonment. The data was displayed using patterns and connections, and conclusions were drawn by visiting the data many times to verify and confirm the themes used (Miles and Huberman, 1994).

\section{Results and Discussions}

\subsection{Effects of Ghanaian Government Construction Projects Abandonment on}

\section{Stakeholders}

\subsubsection{Ranking the effects of project abandonment}

This section assesses the rankings provided by respondents on the effects of Ghanaian Government construction project abandonment. The procedure used is aimed at establishing 
the relative importance of the effects identified as Ghanaian government construction project abandonment. The Relative Importance Index (RII) was calculated using equation 1 (as outlined in Fagbenle et al., 2004):

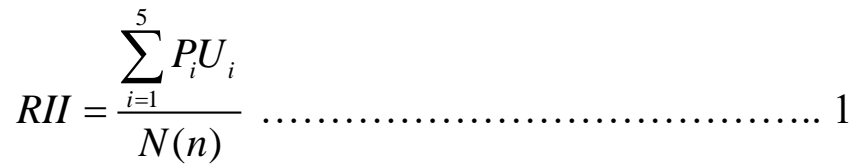

Where,

$\mathrm{RII}=$ relative importance index

$P_{i}=$ respondent's ranking of effects of construction project abandonment

$U_{i}=$ frequency of respondents placing identical ranking on the effects of construction project abandonment

$\mathrm{N}=$ sample size, which in this case (contractors $=69, \mathrm{PMP}=104$ and govt. official $($ client $)=57)$ $\mathrm{n}=$ the highest attainable score on effects of project abandonment, which in this case is 5 $\mathrm{i}=1,2,3,4,5$

The indexes calculated were ranked for contractors, PMP and government officials (clients). The results of the rankings, as well as the overall rankings, are presented in table 2 and 3 respectively.

Table 2: Relative Importance Index and Ranks of Effects of Ghana Government construction project Abandonment

\begin{tabular}{|l|c|c|c|c|c|c|c|}
\hline \multirow{2}{*}{ Factors } & \multicolumn{2}{|c|}{} & \multicolumn{2}{c|}{ PMP } & \multicolumn{2}{c|}{$\begin{array}{c}\text { Govt. Official } \\
\text { (Client) }\end{array}$} & Overall \\
& \multicolumn{2}{|c|}{ Contractor } & \multicolumn{2}{c|}{ PMP } \\
\cline { 2 - 8 } & RII & Rank & RII & Rank & RII & Rank \\
\hline Loss of revenue by state & 0.803 & 3 & 0.696 & 13 & 0.712 & 11 & 7 \\
\hline Emotional stress on citizens & 0.713 & 15 & 0.683 & 16 & 0.635 & 20 & 17 \\
\hline $\begin{array}{l}\text { It slows down citizens human } \\
\text { empowerment }\end{array}$ & 0.751 & 9 & 0.694 & 14 & 0.737 & 5 & 11 \\
\hline
\end{tabular}




\begin{tabular}{|l|c|c|c|c|c|c|c|} 
Government sector underdevelopment & 0.82 & 2 & 0.729 & 8 & 0.733 & 7 & 3 \\
\hline Collapse of local business & 0.632 & 25 & 0.633 & 23 & 0.614 & 26 & 25 \\
\hline Loss of election & 0.739 & 10 & 0.71 & 11 & 0.695 & 14 & 13 \\
\hline It slows down economic growth & 0.774 & 6 & 0.744 & 4 & 0.751 & 2 & 4 \\
\hline Loss foreign Aids/grants & 0.672 & 20 & 0.713 & 10 & 0.719 & 9 & 14 \\
\hline $\begin{array}{l}\text { Financial institution lose confidence in } \\
\text { the state }\end{array}$ & 0.771 & 7 & 0.737 & 7 & 0.747 & 4 & 5 \\
\hline Unemployment & 0.832 & 1 & 0.8 & 1 & 0.793 & 1 & 1 \\
\hline Loss of revenue by the citizens & 0.765 & 8 & 0.69 & 15 & 0.748 & 3 & 10 \\
\hline Strict donor regulation & 0.707 & 16 & 0.669 & 19 & 0.702 & 12 & 16 \\
\hline Cost escalation & 0.678 & 18 & 0.683 & 16 & 0.659 & 18 & 18 \\
\hline Lack of capacity & 0.652 & 22 & 0.637 & 22 & 0.621 & 25 & 24 \\
\hline Loss of worker hours & 0.641 & 24 & 0.673 & 18 & 0.632 & 22 & 22 \\
\hline Gap in infrastructure & 0.739 & 10 & 0.74 & 5 & 0.66 & 17 & 12 \\
\hline Discourages investment & 0.783 & 5 & 0.738 & 6 & 0.72 & 8 & 6 \\
\hline Relocation of services & 0.649 & 23 & 0.665 & 20 & 0.701 & 13 & 19 \\
\hline Accident and Death & 0.678 & 18 & 0.632 & 24 & 0.67 & 16 & 21 \\
\hline Denial of citizens basic right & 0.551 & 26 & 0.596 & 26 & 0.628 & 23 & 26 \\
\hline Armed robbery and theft & 0.681 & 17 & 0.646 & 21 & 0.653 & 19 & 20 \\
\hline Abandonment of homes & 0.67 & 21 & 0.625 & 25 & 0.627 & 24 & 23 \\
\hline Loss of property & 0.728 & 13 & 0.725 & 9 & 0.736 & 6 & 9 \\
\hline Bad image for government & 0.794 & 4 & 0.788 & 2 & 0.716 & 10 & 2 \\
\hline Pollution & 0.722 & 14 & 0.767 & 3 & 0.674 & 15 & 8 \\
\hline Imprisonment of contractors & 0.739 & 10 & 0.7 & 12 & 0.635 & 20 & 15 \\
\hline
\end{tabular}

The contractors ranked unemployment as the biggest effect of Ghanaian government construction project abandonment; this is followed by government sector underdevelopment, loss of revenue by state, bad image for government and discourages investment respectively. PMP ranked unemployment as the biggest effect of Ghanaian government construction project abandonment; this is followed by bad image for the government, pollution, slowdown of economic growth and gap in infrastructure respectively. The government official also unemployment as the biggest effect of Ghanaian government construction project abandonment; this is followed by a slowdown of economic growth, loss of revenue by the citizens, financial institutions lose confidence in state and slowdown in citizens' human empowerment respectively. The top ten overall rankings for the effects in the order of importance are as follows: 
1. Unemployment

2. Bad image for government

3. Government sector underdevelopment

4. It slows down economic growth

5. Financial institutions lose confidence in the state

6. Discourages investment

7. Loss of revenue by state

8. Pollution

9. Loss of properties

10. Loss of revenue by the citizens

\section{Agreement Analysis}

It is important to establish that the rankings provided by the contractors, PMP and the government officials were not due to chance or some form of bias but represent the true effects of Ghanaian government construction project abandonment. To do so, two methods were used - Spearman rank correlation coefficient and Kendall's coefficient of concordance. Both tests are a non-parametric test which means the distribution does not necessarily need to be normal before they can be applied. In other words, the computation uses medians and not means, hence, they are not affected by outliers.

The Spearman rank correlation coefficients $(\rho)$ calculated using equation 2 (as outlined in Fugar and Agyakwah-Baah, 2010):

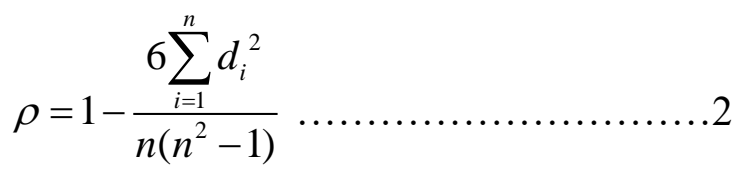

Where, 
$\mathrm{d}=$ the difference between the ranks given by any two categories of respondents for individual effects, in this case, the categories are contractors, PMP and government official $\mathrm{n}=$ the number of causes/factors, which in this case is 26 effects

$\mathrm{i}=1,2,3,4, \ldots \mathrm{n}$

The results of the computation showed a Spearman rank correlation coefficient of $0.789,0.755$ and 0.688 for contractors and PMP; contractors and government officials; and PMP and government officials respectively. Though all three coefficients are strong and positive which shows a high agreement between the rankings of the categories, the pair with the highest agreement is the relationship between contractors and PMP.

It is important to establish using a single coefficient the level of agreement between the three categories. This is where Kendall's Coefficient of Concordance $(W)$ becomes useful. Kendall's $W$ is directly related to the Spearman rank correlation coefficient (Legendre, 2005). Kendall's $W$ is calculated from the mean ( $\rho$ ) of the pairwise Spearman correlations $\left(\rho_{s}\right)$ using equation 3 (As outlined in Siegel and Castellan 1988, p. 262; Zar 1999, p. 448):

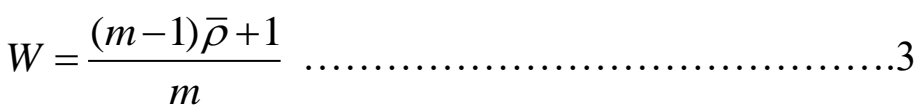

Where, $\mathrm{m}=$ the number of categories of respondents, which in this case is 3 $\bar{\rho}=$ the mean of the pairwise Spearman correlations, which in this case is 0.769 The computed Kendall's $W$ is 0.826 which shows that there exists a high degree of agreement across the categories (contractor, PMP, government official) on the effects of Ghanaian government construction project abandonment. 


\section{Test of Significance (Effects)}

It is important to establish if the extent of agreement/disagreement across the categories is statistically significant. To do so the Chi-Square test is used. First, a hypothesis is formed: Null Hypothesis $\quad=H_{0}=$ There is disagreement in Rankings among the three categories Alternate Hypothesis $=H_{1}=$ There is an agreement in Rankings among the three categories .

The Chi-Square test is also a non-parametric test used to determine if a significant difference exists among the category rankings. There is a relationship between the Chi-Square value and Kendall's $W$ shown in equation 4 (As outlined in Frimpong et al., 2003)

$x^{2}=m(n-1) W$ .4

Where,

$\mathrm{m}=$ the number of categories of respondents, which in this case is 3

$\mathrm{n}=$ the number of effects, which in this case is 26 effects

$W=$ Kendall's coefficient which in this case is 0.846

The result of the computation is $x^{2}=62.2$ and using the critical table for $\mathrm{n}=26$ and $\alpha=0.05$ (That is 95\% confidence interval), the Chi-square critical ratio $=x_{\alpha}^{2(n-1)}=x_{0.05}^{2(25)}=37.65$.

\section{Decision Rule}

Since the computed Chi-Square value $\left(x^{2}=62.2\right)$ is higher than the Chi-Square critical ratio ( $\left.x_{0.05}^{2(25)}=37.65\right)$, we reject the null hypothesis $\left(H_{0}\right)$ and conclude that there is a high degree of agreement among the three categories of the effects of Ghanaian government construction project abandonment. 


\subsubsection{Group Ranking of the Effects of Ghana Government Construction Projects Failure}

In agreement with previous studies (Frimpong et al., 2003; Sambasivan and Soon, 2007; AlKharashi and Skimore, 2009; Fugar and Agyakwah-Baah, 2010), the 26 factors identified as possible effects of Ghana Government construction project abandonment were classified into four groups - namely; economic, social, political and psychological. Internal reliabilities in the form of Cronbach's coefficient alpha $(\alpha)$ were calculated for each of the four groups to assess the reliability of the grouping criteria in the context of this study. Cronbach's alpha values of $0.702,0.622,0.601$ and 0.607 were obtained for economic, social, political and psychological effects respectively, all meeting the minimum of 0.6 suggested by Hair et al (1998) for exploratory research. The factor groups, therefore, show high internal consistencies of the measured variables. The index of each of the four groups was calculated as the average of relative importance index of the individual effects within the group. The results of the rankings, as well as the overall rankings, are shown in table 3.

Table 3: Relative Importance Index and Ranks of Effects of Group of Factors

\begin{tabular}{|c|c|c|c|c|c|c|c|}
\hline \multirow[t]{2}{*}{ Factors } & \multicolumn{2}{|c|}{ Contractor } & \multicolumn{2}{|c|}{ PMP } & \multicolumn{2}{|c|}{$\begin{array}{c}\text { Govt. Official } \\
\text { (Client) }\end{array}$} & \multirow{2}{*}{$\begin{array}{c}\text { Overall } \\
\text { Rank }\end{array}$} \\
\hline & RII & Rank & RII & Rank & RII & Rank & \\
\hline ECONOMIC $(\alpha=0.702)$ & 0.743 & 2 & 0.713 & 2 & 0.712 & 1 & 2 \\
\hline Loss of revenue by state & 0.803 & & 0.696 & & 0.712 & & \\
\hline Government sector underdevelopment & 0.82 & & 0.729 & & 0.733 & & \\
\hline Collapse of local business & 0.632 & & 0.633 & & 0.614 & & \\
\hline It slows down economic growth & 0.774 & & 0.744 & & 0.751 & & \\
\hline Loss foreign Aids/grants & 0.672 & & 0.713 & & 0.719 & & \\
\hline $\begin{array}{l}\text { Financial institution lose confidence in } \\
\text { the state }\end{array}$ & 0.771 & & 0.737 & & 0.747 & & \\
\hline Unemployment & 0.832 & & 0.8 & & 0.793 & & \\
\hline Loss of revenue by the citizens & 0.765 & & 0.69 & & 0.748 & & \\
\hline Cost escalation & 0.678 & & 0.683 & & 0.659 & & \\
\hline Loss of worker hours & 0.641 & & 0.673 & & 0.632 & & \\
\hline Discourages investment & 0.783 & & 0.738 & & 0.72 & & \\
\hline SOCIAL $(\alpha=0.622)$ & 0.682 & 4 & 0.673 & 4 & 0.671 & 3 & 4 \\
\hline
\end{tabular}




\begin{tabular}{|c|c|c|c|c|c|c|c|}
\hline $\begin{array}{l}\text { It slows down citizens human } \\
\text { empowerment }\end{array}$ & 0.751 & & 0.694 & & 0.737 & & \\
\hline Lack of capacity & 0.652 & & 0.637 & & 0.621 & & \\
\hline Loss of property & 0.728 & & 0.725 & & 0.736 & & \\
\hline Gap in infrastructure & 0.739 & & 0.74 & & 0.66 & & \\
\hline Relocation of services & 0.649 & & 0.665 & & 0.701 & & \\
\hline Accident and Death & 0.678 & & 0.632 & & 0.67 & & \\
\hline Denial of citizens basic right & 0.551 & & 0.596 & & 0.628 & & \\
\hline Armed robbery and theft & 0.681 & & 0.646 & & 0.653 & & \\
\hline Abandonment of homes & 0.67 & & 0.625 & & 0.627 & & \\
\hline Pollution & 0.722 & & 0.767 & & 0.674 & & \\
\hline POLITICAL $(\alpha=0.601)$ & 0.747 & 1 & 0.722 & 1 & 0.704 & 2 & 1 \\
\hline Loss of election & 0.739 & & 0.71 & & 0.695 & & \\
\hline Bad image of government & 0.794 & & 0.788 & & 0.716 & & \\
\hline Strict donor regulation & 0.707 & & 0.669 & & 0.702 & & \\
\hline PSYCHOLOGICAL $(\alpha=0.607)$ & 0.726 & 3 & 0.692 & 3 & 0.635 & 4 & 3 \\
\hline Emotional stress on citizens & 0.713 & & 0.683 & & 0.635 & & \\
\hline Imprisonment of contractors & 0.739 & & 0.7 & & 0.635 & & \\
\hline
\end{tabular}

In the grouping analyses, both contractors and PMP unanimously agreed that political effect is the most significant effect of Ghana government construction project abandonment, followed by economic, psychological and social effects respectively. On the other hand, government officials identified economic effect as the most significant effect of Ghana government construction project abandonment, followed by political, social and psychological effects respectively.

Overall (across three categories of respondents), political effects were found to be the most significant effect of Ghana government construction project abandonment, followed by economic, psychological and social effects respectively. 


\subsection{How Stakeholders of Construction Projects Abandonment are Affected}

This section presents and discusses the findings from the interviews conducted after the questionnaire results. The purpose was to get deeper and further understanding of how construction projects affect the stakeholders identified with such projects. The findings are presented using the themes used for the questionnaire analysis.

\subsubsection{Economic effects on stakeholders}

According to the respondents, the Ghanaian government incurs additional costs for construction projects abandonment. They are of the view that when these projects are abandoned, contractors sometimes sue the government for compensation due to their loss in investment in the projects. For instance, respondents R2, R5, R6 and R9 argued that government waste money on such projects because they have been abandoned especially if the construction project has been abandoned as a result of a change in government.

Look, this kind of incurring additional cost is common after a change in government. They would deliberately abandon the projects and then re-award it to their party members, so the other contractor would sue the government for compensation. These people (politicians) do not care about these additional costs because it's not their personal money (R2).

Moreover, if construction projects are abandoned, sometimes the money is lost to the project for good and this has direct effects on the government and its chances of winning the next general elections. Consequently, this affects the Ghanaian budget directly - increasing the budget deficit (R1, R3, R4, R15 \& R16).

Respondents perceived that unemployment increases when Ghanaian government construction projects are abandoned. The country has high levels of unemployed youths and therefore, abandonment of construction projects adds to the problem. This has direct effects on 
the citizens and indirect effects on the government. R6, for instance, is of the view that the effects of abandoned educational building construction projects are:

lack of spaces for, say, engineers to be trained; and there are a number of multi-million projects being run by foreign nationals, and some of them come here and realise that some of the local competencies are not there, [so] they are forced to go elsewhere for expatriates to come and do it. Unemployment keeps rising because these people cannot fit into the system.

Interviewees (R2, R3, R4 \& R9) opined that Ghanaian government projects abandonment means that man-hours are lost because the workers may go to work and would be idle. Further, if there is road construction project abandonment, there would be an increase in road traffic and therefore 'cars move extremely slowly and this creates inconvenience to motorists and those going to work would lose man-hours to these traffics' (R2). In this case, they perceive that the government loses economically. Like the government, contractors also lose money through the abandonment of construction projects. They argued that in most cases, contractors use credit facilities for the execution of these projects and therefore abandonment means that they may not be able to service their credit agreements because the government might not be willing to release their contract sums to them because the project is no more useful for the government; and for the fear of not getting more contracts from the government may not result to legal suit, hence, loss of capital.

My brother, most contractors, especially local ones would normally not sue the government for fear of not getting further contracts but the foreign ones usually sue for their money. If you meet them in secret, they would tell you this but when the media calls them, they would pretend as if all is well (R13).

The long-term effect of the construction project abandonment is stagnation of economic growth of the country as a whole and this has consequences on the economic development of the 
citizens, hence, their standard of living. In the words of R4, 'construction projects abandonment, just like any other government project failure brings about economic hardship on citizens'. Further, respondents perceive that construction projects abandonment discourages investment, especially if the construction is within the road sector -in the area of foreign direct investment may be affected greatly. R2 argued that,

government project failure discourages investments, more especially foreign investors, especially in the road sector... how do you want me to build factories in areas where road construction has been abandoned? You can't have access to such areas so that you can transport your produce.

Like development projects, the ultimate aim of Ghanaian government construction projects is to improve the socio-economic standards of the general public (Ahsan and Gunawan, 2010; Ngacho and Das, 2014; Yang, 2014). Therefore, abandonment implies that the economic wellbeing of the citizens is affected and subsequently, the country's economic development is affected.

Construction projects abandonment also implies that the country may lose foreign aid/grant. As stated earlier, Ghana relies heavily on foreign donors to finance its projects and therefore, abandonment means that they would be unwilling to release further funds. Financial institutions, especially IMF and World Bank may lose confidence in the country and may not be willing to funds such projects again.

\subsubsection{Social effects on stakeholders}

Respondents perceive that one of the main reasons for construction projects implementation is to improve the social well-being of the citizens and therefore abandonment implies that the social well-being is also abandoned. 
Abandonment of Ghana government construction is equal to the abandonment of the social wellbeing of the ordinary Ghanaian. The social implications for abandonment are many and I can't even remember all of them. For example, basic infrastructural needs such as school buildings, toilets, water (groundwater constructions common in rural areas) would be denied. If you take to school as an example, children's fundamental right to education may be denied (R9).

When children are denied their basic right such as education as a result of education construction projects abandonment, they tend to give birth at an early age (teenage pregnancy) and become 'irresponsible fathers and mothers' (R5), and therefore, they have no hope in life. Two respondents even trace life success in the country to the 'sort of parents you have ... and that teenage pregnancy is associated with vagabonds who smoke weed and those engaged in armed robbery and prostitution' (R4 \& R5) in the society. The cycle would then continue (R5).

One respondent perceives that abandonment makes life more difficult for the immediate residents of the projects environs. In the words of R2 abandonment:

makes life difficult for local people as they have to travel all the way to another suburb to access these amenities. They sometimes lose their service lines such as electricity, water, and telephones lines during the execution of some construction projects with the aim that when the project is completed, they would be restored, so abandonment means that they may never get them back. Because they don't have access to these facilities, life in their homes becomes more difficult. Sometimes, their electrical gadgets are destroyed without [them] being compensated.

Similarly, in some circumstance, people lose their homes and other properties to these projects and may be relocated with the aim that when the projects are over, they may be able to come back. In some circumstance, the government promises to build their homes as part of the project, and the implication is that once these projects have been abandoned, they may not be able to have their homes back on time as promised and these may sometimes lead to long protracted court cases. Interviewee R9 said that: 
these people are not normally compensated by [the] government because their homes are not being pulled down or destroyed and therefore [they] could stay in them or could return after project completion.

Social vices which affect the citizens and governments were also revealed by respondents are major effects of construction projects abandonment. R2, for example, said that, when construction projects are abandoned (especially buildings), it may lead to armed robbery and theft. He said "Area boys" (Gangs) use these abandoned facilities as a hide-out to execute their armed robbery and theft activities. Further, if there are no electricity or telephone lines, criminals are able to operate without being caught, simply because there is no light for them to be visible to onlookers and no telephone with which to call the police and report the crime. Accordingly, these activities may lead to deaths (R1, R2, R3, R4). They also perceive that abandonment may also lead to deaths of ordinary citizens if the construction project is in the healthcare sector (R2, R7, R8). R8, in particular, argues that:

My brother, if government abandons healthcare construction projects in say a village - where there are no other healthcare facilities, what do you think would happen to the rural folks? There are countless instances where even pregnant people die simply because there are no healthcare facilities. And when you do the research, you would know that a construction of such facilities has been abandoned for ages. You can ask the media, they always report these incidents but the politicians don't care.

They further perceive that the citizens may die as result of construction projects being abandoned because some of the may leave death-traps such as holes where some people may fall into them and die. They are of the view that, in Ghana, health and safety management; and risk prevention at construction sites are very poor, and therefore, abandoned construction projects have the potential hazard to kill citizens as a result of these sites debris are left unattended. 
They also perceive that construction projects abandonment often leads to pollution in the form of noise, dust, and air (R2, R9 \& R10). This may cause diseases that may put strains on healthcare facilities and if proper care is not sorted, may lead to death. As a result of this, 'it also creates [a great] burden on the healthcare facilities in the country, as sick people would seek medical attention' (R9). The end effect is ozone layer depletion; which affects the environment (R9).

Prior studies have concluded that developmental projects are meant to provide goods and services to enhance the life of the citizens of the implementing countries (Ahsan and Gunawan, 2010; Ngacho and Das, 2014; Yang, 2014); hence, the implication is that failure would affect their social well-being. Thus, although the effects have not been fully discussed, a deduction can be made from these prior studies and this research. If developmental projects are purported to improve the social well-being of the citizens, then abandonment would affect the citizens' social life.

\subsubsection{Political effects on stakeholders}

The study revealed that Ghanaian government construction projects are highly 'political', and therefore, the political implication of abandonment is huge. Three main effects were identified - loss of the election, bad image of government and strict donor regulation. The study revealed that the main reason for any Ghanaian government losing general elections is project performance; especially in the rural areas where most of the residents are illiterate. In such places and even some of the urban areas, majority of the citizens do not understand economic issues such as economic growth rate, GDP, inflation, fiscal and monetary policies and other economic indicators - all that they are interested in is seeing projects in their communities, and therefore, if government construction projects are abandoned, the implication is that the government is not performing (R2, R6, R7, R8 \& R10). Abandonment dents the image of the 
party in power, hence, affecting its chances of winning the next general elections. If government construction project fails, 'it is not going to be palatable for the government' (R6). In the words of R2:

ordinary Ghanaians don't know what GDP, micro or macroeconomic, economic indicators, inflation, fiscal and monetary policies and those issues are ... what they know is physical infrastructures. In fact, I will say projects, especially infrastructure projects, are the main yardstick to measure government performance in this country by the ordinary man on the street.

The practitioner (R2) estimates that Ghanaian government projects performance can influence general election results by approximately $50 \%$. 'That is why, when elections are close, [the] government starts a lot of projects and commissions a lot' (R2). R8 on the other hand, estimate this effect as approximately $35 \%$. The implication is that it is not only the incumbent party that construction projects abandonment affect but also the opposition parties - as their previous construction projects performance may be compared to that of the party in power.

Further, construction projects abandonment leads to donor and other external financial institutions such as IMF and World imposing stricter regulations and rules on the government. The implication is that this action(s) does not only affect the central government but also the general public. Some of these regulations may lead to suspension of government subsidies on basic social amenities and freezing of public sector employment.

\subsubsection{Psychological effects on stakeholders}

Closely related to social effects is a psychological effect. It was found that the psychological effect of Ghanaian government construction project abandonment is huge. These include emotional stress on citizens and imprisonment of contractors. Even though these effects came last in the rankings, the interviewees stressed that it should not be underestimated. For instance, R5 stressed that: 
in this country, we don't care about emotional and psychological problems ... because of poverty, we take don't take these emotional and psychological issues for granted but they are real among people. Elsewhere like the UK, where I used to work, they take these things seriously and have departments in charge of dealing with these issues.

However, these effects appear direct and indirect. For instance, if construction projects are abandoned, one of the direct effects is that people lose their businesses and jobs, and if they lose their business, it affects their psyche. Sometimes, they may lose hope in life altogether.

Further, as discussed under the economic effects, when contractors default on their credits, creditors (especially financial institutions) sue them for their money and in some extreme circumstances, they are imprisoned. Similarly, Adams (2008) found that Ghanaian contractor who defaults credit and/or goes bankrupt are imprisoned. The victim(s) and their family are stigmatised, hence, losing respect in society. Ghanaian practices extended family system where the family bond is the focus for respect, recognition, and identity (The Hofsede, 2016) and therefore, anything that happens to any member of the family affects the entire family. This finding provides a unique dimension to project management literature, as previous literature has not discussed these effects and how stakeholders are affected.

\section{Conclusions}

The construction industry of every country drives economic growth as it serves as the foundation for other sectors' growth and as such, the need to manage projects in this sector cannot be overemphasised. However, in developing countries, some of these projects fail through abandonment but researchers have not paid attention to the effects that these abandoned construction projects have on stakeholders associated with such projects. This study, therefore, investigated the effects of government construction abandonment on stakeholders associated with such projects by focusing on Ghana. Using sequential data 
collection approach through focused-group discussions, questionnaire and an in-depth semistructured interview, twenty-six (26) effects of construction projects abandonment on stakeholders are identified. The top ten most important effects are unemployment, bad image for the government, government sector underdevelopment, it slows down economic growth, financial institutions lose confidence in the state, discourages investment, loss of revenue by state, pollution, loss of properties, and loss of revenue by the citizens.

These effects were grouped into four main areas and are: economic, social, political and psychological. However, these effects were interrelated and cyclical in nature. Some economic effects many leads to social effects and in that order. It could also be argued that whereas some are direct on some stakeholders, others are indirect. In the areas of the economic effects, for instance, the direct effects are mainly on the general populace as they are the main beneficiaries of government projects whilst the indirect effects may be on the government in power, hence, political effect. This finding is similar to the work of Ahsan and Gunawan (2010), Ngacho and Das (2014) and Yang (2014) but they only made mention of these types of effects without discussing how stakeholders may be affected.

Moreover, social effects of Ghanaian government construction projects abandonment are huge. However, these effects are mainly traced to the ordinary citizens despite the fact that in the immediate term, other stakeholders such as the government, financial institutions and contractors may also be affected in some sort.

Further, political effects are mainly on the part of the government and the opposition parties who may rely on government constriction projects performance for general elections performance. The reason being that majority of citizens are illiterates with less knowledge about economic indicates and therefore use government physical infrastructure projects performance as a yardstick to judge government performance, hence, influencing their voting. 
In addition, the study found that the psychological effects appear to be indirect but need much attention. The study found that even though abandoned construction projects have huge psychological effects on the citizens, businessmen/contractors, attention has not been paid to these effects due to the fact that the country is a developing country with high levels of poverty and such as people do not care soo much about emotional and psychological issues that may confront people in the society.

Overall, the research indicates that whilst some of these effects on stakeholders are direct, others are indirect and cyclical in nature. In addition, some of these stakeholders might not be affected greatly. For instance, the foreign donors/countries may be affected as they may not be able to realise their targeted purpose as a result of the abandoned projects but it may not directly affect their activities or finances. The only way it may affect them is if they have the intention of investing in the country through other business activities such as direct foreign investment.

\section{Reference}

Abdullah, A. A., Alias, A., Ting, K. H., and Mei, G. N., 2014. The causes and effects of housing project abandonment in Malaysia. World Academy of Science, Engineering and Technology Civil and Environmental Engineering. International Scholarly and Scientific Research \& Innovation, 1(12). ICSCE 2014: 18th International Conference on Structural and Construction Engineering. London-UK.

Adams, F. K., 2008. Risk perception and Bayesian analysis of international construction contract risks: The case of payment delays in developing economy. International Journal of Project Management, 26(2), 138-148.

Agarwal, N., Rathod, U., 2006. Defining 'success' for software projects: An exploratory revelation. International Journal of Project Management, 24(4), 358-370. 
Ahadzie, D. K., Proverbs, D. G., Olomolaiye, P. O., Ankrah, N. A., 2009. Competencies required by project managers for housing construction in Ghana: Implications for CPD agenda. Engineering, Construction and Architectural Management, 16(4), 353 - 375.

Ahsan, K., Gunawan, I., 2010. Analysis of cost and schedule performance of international developmental projects. International Journal of Project Management, 28(1), 68-78.

Al-Kharashi, A. and Skimore, M., 2009. Causes of delays in Saudi Arabian public sector construction projects. Journal of Construction Management and Economics, 27(1), 323.

Al-Khalil, M. I., Al-Ghafly, M. A., 1999. Important causes of delay in public utility projects in Saudi Arabia. Journal of Construction Management and Economics, 17(5), 647-655.

Ainuddin, R.A., Beamish, P. W., Hulland, J. S., Rouse, M. J., 2007. Resource attributes and firm performance in international joint ventures. Journal of World Business, 42, 47-60.

Alexander, I., Stevens, R., 2002. Writing better requirements. Addison Wesley, Reading

Alexander, I., Robertson, S., 2004. Understanding project sociology by modeling stakeholders. IEEE Software IEEE Computer Society, 21(1), 23-27.

Alic, J. A., 2008. A weakness in diffusion: US technology and science policy after World War II. Technology in Society, 30(1), 17-29.

Amoatey, C. T., Ameyaw, Y. A., Adaku, E., Famiyeh, S., 2015. Analysing delay causes and effects in Ghanaian state housing construction projects. International Journal of Managing Projects in Business, 8(1), 198 - 214.

Amponsah, R., 2010. Improving Project Management Practice in Ghana with Focus on Agriculture, Banking and Construction Sectors of the Ghanaian Economy. A thesis submitted in fulfillment of the requirements for the Degree of Doctor of Project Management. School of Property, Construction and Project Management RMIT University. 
Assaf, S. A., Al-Hejji, S., 2006. Causes of delay in large construction projects. International Journal of Project Management, 24(4), 349-357.

Aryeetey, E., Jane, H., 2000. Economic Reforms in Ghana: The Miracle and the Mirage 'Macroeconomic and Sectoral Developments since the 1970s', (ed) Ernest Aryeetey, Jane Harrigan, and Machiko Nissanke, (London: James Curry, Ltd, UK, 2000).

Axelsson, K., Melin, U., Lindgren, I., 2013. Public e-services for agency efficiency and citizen benefit - Findings from a stakeholder centered analysis. Government Information Quarterly, 30(1), 10-22.

Ayodele, E. O., Alabi, O. M., 2011. Abandonment of Construction Projects in Nigeria: Causes and Effects. Journal of Emerging Trends in Economics and Management Sciences, 2(2), 142-145.

Ballejos, L. C., Montagna, J. M., 2008. Method for stakeholder identification in interorganizational environments. Requirement Engineering, 13, 281-297

Carrero, R., Malvárez, G. Navas F., Tejada, M., 2009. Negative impacts of abandoned urbanisation projects in the Spanish coast and its regulation in the Law. Journal of Coastal Research, 56, 1120-1124.

Damoah, I. S., 2015. An investigation into the causes and effects of project failure in government projects in developing countries: Ghana as a case study. A thesis submitted in fulfillment of the requirements for the Degree of Doctor of Project Management. Liverpool John Moores University.

Damoah, I. S., Akwei, C. 2017. Government project failure in Ghana: a multidimensional approach. International Journal of Managing Projects in Business, 10(1), 32-59. 
Damoah, I. S., Akwei, C., Mouzughi, Y., 2015. Causes of government project failure in developing countries - Focus on Ghana. In: The Value of Pluralism in Advancing Management Research, Education and Practice. 29th Annual BAM Conference 8-10 September 2015. University of Portsmouth.

Economy Watch, 2011. 12 Fastest Growing Economies of 2011. Available at: http://www.economywatch.com/economy-business-and-finance-news/12-fastestgrowing-economies-of-2011-8-12.html?page=full- (accessed 4 October 2013).

Efenudu, F. O., 2010. Causes and Effect of Abandonment of Project on Property Value; A Case of Port Harcourt; Unpublished First Degree Dissertation, Department of Estate Management, Faculty of Environmental Sciences, Rivers State University of Science and Technology, Nigeria.

Eichengreen, B., 1994. Restructuring and Adjustment: perspectives from Post-World II Europe. Institutional prerequisites for economic growth: Europe after World War II. European Economic Review, 38, 883-890.

Eichengreen, B., 1996. Institutions and Economic Growth: Europe Since World War II, in N. F. R. Crafts and Gianni Toniolo (eds), Economic Growth in Europe Since 1945. Cambridge: Cambridge University Press, pp.38-72.

Eichengreen, B., Vazquez, P., 1999. Institutions and Economic Growth in Postwar Europe: Evidence and Conjectures. Productivity, Technology and Economic Growth, 91-128.

Elias, A. A., Cavana, R. Y., Jackson, L. S., 2002. Stakeholder analysis for R \& D project management. $R \& D$ Management, 32(4), 301-310.

Fabian, C., Amir, A., 2011. The Chad-Cameroon Pipeline Project--Assessing the World Bank's Failed Experiment to Direct Oil Revenues towards the Poor. The Law and Development Review, 4(1), 32-65. 
Fagbenle, O. I., Adeyemi, A. Y., Adesanya, D. A., 2004. The impact of non-financial incentives on briclayers' productivity in Nigeria. Construction Management and Economics, 22, 899-911.

Faridi, A. S., El-Sayegh, S. M., 2006. Significant factors causing delay in the UAE construction industry. Construction Management and Economics, 24(11), 1167-1176.

Flak, L. S., Nordheim, S., 2006. Stakeholders, contradictions and salience: An empirical study of a Norwegian G2G effort. Proceedings of the 39th annual Hawaii international conference on system sciences (HICSS).

Fontaine, C., Haarman, A., Schmid, S., 2006. The Stakeholder Theory of MNC. Available at: http://www.edalys.fr/documents/Stakeholders\%20theory.pdf. (Accessed 23 March 2016).

Freeman, R. E., 1984. Strategic Management: A Stakeholder Approach. Latest edition Strategic Management: A Stakeholder Approach. Boston: Pitman.

Frimpong, Y., Oluwoye, J., Crawford, L., 2003. Causes of delay and cost overruns in construction of groundwater projects in developing countries; Ghana as a case study. International Journal of Project Management, 21(5), 321-326.

Fugar, F. D. K., Agyakwah-Baah, A. B., 2010. Delays in building construction projects in Ghana. Australasian Journal of Construction Economics and Building, 10(1-2), 103116.

Ghana Statistical Service, 2015. Provisional Gross Domestic Product 2013. Ghana Statistical Service, Accra-Ghana, September, 2015.

Guest, G., Bunce, A., Johnson, L., 2006. How Many Interviews are Enough? An Experiment With Data Saturation and Variability. Field Methods, 18(16),59-82.

Hair, J. F. J., Anderson, R. E., Tatham, R. L., Black, W. C., 1998. Multivariate Data Analysis, Prentice-Hall, Upper Saddle River, NJ. 
Heath, J., Norman, W., 2004. Stakeholder Theory, Corporate Governance and Public Management; What can the history of state-run enterprises teach us in the post-Enron era? Journal of Business Ethics, 53(3), 247-265.

Hill, C. E., Knox, S., Thompson, B. J., Williams, E. N., Hess, S. A., Ladany, N., 2005. Consensual qualitative research: An update. Journal of Counselling Psychology, 52(2), $1-30$.

Hillman, A. J., Withers, M. C., Collins B. J., 2009. Resource dependence theory: A review. Journal of Management, 35: 1404-1427.

Hogberg, O., Adamsson, A., 1983. A Scandinavian view of project management. International Journal of Project Management, 1(4), 216-219.

Horta, I. M., Camanho, A. S., da Costa, J. M., 2012. Performance assessment of construction companies: A study of factors promoting financial soundness and innovation in the industry. International Journal of Production Economics, 137, 84-93.

Hwang, B., Ng, W. J., 2013. Project management knowledge and skills for green construction: Overcoming challenges. International Journal of Project Management, 31(2), 272-284.

Jeffries, R., 1982. Rawlings and the political economy of underdevelopment in Ghana. African Affairs. 81, 307-317.

Ke, Y., Wang, S., Chan, A., Cheung, E., 2009. Research trend of public-private partnership in construction journals. Journal of Construction Engineering Management. 135, 10761086

Klutse, F. D., 2009. Affordable housing units for Ghana, 12 March 2009. Available at: https://www.modernghana.com/news/206139/1/affordable-housing-units-forghana.html. (Accessed 20 May 2016).

Khan, K.S., Kunz, R., Kleijnen, J., Antes, G., 2003. Five steps to conducting a systematic review. Journal of Royal Society of Medicine, 96, 118-121. 
Khoshgoftar, M., Bakar, A. H. A., Osman, O., 2014. Causes of Delays in Iranian Construction Projects. International Journal of Construction Management, 10(2), 53-69.

Legendre, P., 2005. Species Associations: The Kendall Coefficient of Concordance Revisited”, American Statistical Association and the International Biometric Society Journal of Agricultural, Biological, and Environmental Statistics, 10(2), 226-245.

Lu, W., Liu, J., 2014. Research into the moderating effects of progress and quality performance in project dispute negotiation. International Journal of Project Management, 32, 654662.

Israel, G. D., 1992. Determining sample size. University of Florida Cooperative Extension Service, Institute of Food and Agriculture Sciences, EDIS.

Miles, M., Huberman, M., 1994. The Handbook of Social Work Research Method. London: Sage Publication.

Mishmish, M., El-Sayegh, S. M., 2016. Causes of claims in road construction projects in the UAE. International Journal of Construction Management, 1-8. doi.org/10.1080/15623599.2016.1230959.

Mitchell, R. K., Agle, R. B., Wood, J. D., 1997. Toward a Theory of Stakeholder Identification and Salience: Defining the Principle of Who and What Really Counts. The Academy of Management Review, 22(4), 853-886.

Mok, K. Y., Shen, G. Q., Yang, J., 2015. Stakeholder management studies in mega construction projects: A review and future directions. International Journal of Project Management, 33(2), 446-457.

Morse, J. M., 1995. The significance of saturation. Qualitative Health Research, 5(2), 147-149.

Morse, J. M., 2000. Determining sample size. Qualitative Health Research, 10(1), 3-5. 
Mukabeta, B., Owei, V., Alexander, H., 2008. Questioning the pace and pathway of egovernment development in Africa: A case study of South Africa's Cape Gateway Project. Government Information Quarterly, 25(4), 757-777.

Muya, M., Kaliba, C., Sichombo. B., Shakantu, W., 2013. Cost Escalation, Schedule Overruns and Quality Shortfalls on Construction Projects: The Case of Zambia. . International Journal of Construction Management, 13(1), 53-68.

Ngacho, C., Das, D., 2014. A performance evaluation framework of development projects: An empirical study of Constituency Development Fund (CDF) construction projects in Kenya. International Journal of Project Management, 32(3), 492-507.

Odeh, A. M., Battaineh, H. T., 2002. Causes of construction delays: traditional contracts. International Journal of Project Management, 20(1), 67-73.

Ofori, G. 2012. Developing the Construction Industry in Ghana: The Case for a Central Agency. National University of Singapore, Singapore. Available at: www.ghanatrade.gov.gh/file/Developing\%20the\%20Construction\%20Industry\%20in \%20Ghana\%20BUILDING.pdf. (Accessed 10 March 2017).

Olander, S., 2007. Stakeholder impact analysis in construction project management. Construction Management and Economics, 25(3), 277-287.

Pan, G. S. C., 2005. Information systems project abandonment: a stakeholder analysis. International Journal of Project Management, Vol.25, No.2; pp.173-184

Pan, G., Pan, S. L., 2006. Examining the coalition dynamics affecting IS project abandonment decision-making. Decision Support Systems, 42(2), 639-655.

Pero, M., Stößlein, M., Cigolini, R., 2015. Linking product modularity to supply chain integration in the construction and shipbuilding industries. International Journal of Production Economics, 170, 602-615. 
Pourrostam, T., Ismail, A., 2011. Significant Factors Causing and effects of Delay in Iranian Construction Projects. Australian Journal of Basic and Applied Sciences, 5(7), 45-450.

Robertson, S., 2000. Project sociology: identifying and involving the stakeholders. The Atlantic Systems Guild. Available at: www.systemsguild.com.Online: http://www.guild.demon.co.uk/ProjectSociology.Pdf. (Accessed 10 December 2016).

Ruuskaa, I., Teigland, R., 2009. Ensuring project success through collective competence and creative conflict in public-private partnerships - A case study of Bygga Villa, a Swedish triple helix e-government initiative. International Journal of Project Management, 27(4), 323-334.

Saad, M., Cicmil, S., Greenwood, M., 2002. Technology transfer projects in developing countries- furthering the project management perspectives. International Journal of Project Management, 20(8), 617-625.

Saebo, O., Flak, L. S., Sein, M. K., 2011. Understanding the dynamics in e-Participation Initiatives: Looking through the Genre and Stakeholder lenses. Government Information Quarterly, 28(3), 416-425.

Sambasivan, M., Soon, Y. W., 2007. Causes and effects of delays in Malaysian Construction Industry. International Journal of Project Management, 25(5), 517-526.

Saunders, M., Lewis, P., Thorntonhill, A., 2012. Research Methods for Business Students 6th ed. Harlow, England.

Shehu, Z., Endut, I. R., Akintoye, A., Holt, G. D., 2014. Cost overrun in the Malaysian construction industry projects: A deeper insight. International Journal of Project Management, 32(8), 1471-1480.

Siegel, S., Castellan, N. J. J., 1988. Nonparametric Statistics for the Behavioral Sciences. (2nd Ed.), New York: McGraw-Hill.

Silverman, D., 2013. Doing Qualitative Research. (4th Ed). Sage Publication, London. 
Sinesilassie, E. G., Tabish, S. Z. S., Jha, K. N., 2017. Critical factors affecting cost performance: a case of Ethiopian public construction projects. International Journal of Construction Management, 17(1), 1-12.

Short, E. J., 2010. The anti-corruption mandates of the commission on Human Right and Administrative Justice and Serious Fraud Office: A duplication of functions? Institute of Economic Affairs (IEA) - Ghana.

Soderlund, J., 2004. Building theories of project management: past research, questions for the future. International Journal of Project Management, 22(3),183-191.

Sweis, G., Hammad, A. A., Shboul, A., 2008. Delays in construction projects: The case of Jordan. International Journal of Project Management, 26(6), 665-674.

The Hofstede Centre, 2016. What about Ghana?, Available at: http://geerthofstede.com/ghana.html. (Accessed 4 March 2016).

Toor, S. U. R., Stephen O. Ogunlana, S. O., 2008. Problems causing delays in major construction projects in Thailand. Construction Management and Economics, 26(4), $395-408$.

Transparency International (TI), 2008. Corruption Perception Index 2008. Available at: http://www.transparency.org/research/cpi/cpi_2008/0/. (Accessed 17 June 2016).

Transparency International (TI), 2015. Corruption Perception Index 2015. Available at: http://www.transparency.org/cpi2015\#results-table. (Accessed 17 June 2016).

Tranfield, D., Denyer, D., Smart, P., 2003. Towards a methodology for developing evidenceinformed management knowledge by means of systematic review. British Journal of Management 14, 207-222.

World Bank, 2012. Ghana Projects \& Programs. Available at: http://www.worldbank.org/en/country/ghana/projects. (Accessed 29 October 2015). 
Woka, I. P., and Miebaka, B. A., 2014. An assessment of the causes and effects of abandonment of development projects on real property values in Nigeria. International Journal of Research in Applied, Natural and Social Sciences, 2(5), 25-36.

Zar, J. H., 1999. Biostatistical Analysis. (4th ed.). Upper Saddle River, New Jersey: Prentice Hall.

\section{APPENDIX}

\section{(A) Questionnaire Participants Background Information}

Table 4: Background Information of Respondents

\begin{tabular}{|c|c|c|}
\hline Variables & Frequency & Percent \\
\hline \multicolumn{3}{|l|}{ Gender } \\
\hline Male & 194 & 84.3 \\
\hline Female & 36 & 15.7 \\
\hline \multicolumn{3}{|l|}{ Age group } \\
\hline Below 20 & 3 & 1.3 \\
\hline $20-30$ & 121 & 52.6 \\
\hline $31-40$ & 91 & 39.6 \\
\hline $41-50$ & 12 & 5.2 \\
\hline Above 50 & 3 & 1.3 \\
\hline \multicolumn{3}{|l|}{ Total } \\
\hline \multicolumn{3}{|l|}{ Region } \\
\hline Greater Accra & 141 & 61.3 \\
\hline Ashanti & 21 & 9.1 \\
\hline Brong-Ahafo & 7 & 3 \\
\hline Eastern & 5 & 2.2 \\
\hline Central & 8 & 3.5 \\
\hline Volta & 16 & 7 \\
\hline
\end{tabular}


Highest Level of Education

High school

HND

Bachelor

$41 \quad 17.8$

Master's degree

$63 \quad 27.4$

Professional qualification

$\mathrm{PhD}$

\section{Position at Work}

Corporate management

Senior management

Junior management

Supervisory

47

20.4

Subordinate

\section{Category of Respondent}

Contractor

Project management practitioner

Government official (Client)
69

\section{Years of Experience at Current Position}

less than 1 year

25

1-5 years

137

6-10 years 
11-15 years

16-20 years

21-25 years

Years of Experience in General

less than 1 year

$1-5 y r s$

6-10yrs

11-15yrs

16-20yrs

21-25yrs

Sector

Public

Private

Both

Industry

Retail/Wholesale

Manufacturing

Construction

Service

Agriculture

Total
13

4

3

1.3

5.7

1.7

$10 \quad 4.3$

$107 \quad 46.5$

$79 \quad 34.3$

$25 \quad 10.9$

$7 \quad 3.0$

$\begin{array}{ll}2 & 0.9\end{array}$

$72 \quad 31.3$

$\begin{array}{ll}8 & 3.5\end{array}$

$5 \quad 2.2$

$\begin{array}{ll}4 & 1.7\end{array}$

$138 \quad 60.0$

$74 \quad 32.2$

9
9

$230 \quad 100.0$

\section{(B) Interviewees' Profile}

Table 5. In-depth Semi-structured Interview Profile 


\begin{tabular}{|c|c|c|c|c|c|c|c|}
\hline Respondents & Age & Education & $\begin{array}{l}\text { Years of } \\
\text { Experience } \\
\text { in Current } \\
\text { position }\end{array}$ & $\begin{array}{l}\text { Work } \\
\text { Experience } \\
\text { In Project } \\
\text { Management } \\
\text { /Implementa } \\
\text { tion }\end{array}$ & $\begin{array}{l}\text { Overall Work } \\
\text { Experience }\end{array}$ & Industry & Sector \\
\hline \multicolumn{8}{|c|}{ PROJECT MANAGEMENT PRACTITIONERS } \\
\hline $\begin{array}{l}\text { R1(Project } \\
\text { Manager) }\end{array}$ & 61 & Masters & 7 & 15 & 37 & General & $\begin{array}{l}\text { Private \& } \\
\text { Public }\end{array}$ \\
\hline $\begin{array}{l}\text { R2 (Project and } \\
\text { Programmes } \\
\text { Consultant) }\end{array}$ & 57 & $\begin{array}{l}\mathrm{PhD} / \\
\text { Professional }\end{array}$ & 12 & 15 & 32 & General & $\begin{array}{l}\text { Public \& } \\
\text { Private }\end{array}$ \\
\hline R3 (Architect) & 37 & $\begin{array}{l}\text { BA/ } \\
\text { Professional }\end{array}$ & 4 & 10 & 10 & Construction & Public \\
\hline $\begin{array}{l}\text { R4 (Structural } \\
\text { Engineer) }\end{array}$ & 40 & $\begin{array}{l}\text { BA/ } \\
\text { Professional }\end{array}$ & 4 & 14 & 14 & Construction & Public \\
\hline R5 (Administrator) & 45 & BSc & 15 & 15 & 21 & Construction & $\begin{array}{l}\text { Public \& } \\
\text { Private }\end{array}$ \\
\hline R6 (Civil Engineer) & 57 & $\begin{array}{l}\text { BSc/Professio } \\
\text { nal }\end{array}$ & 1 & 20 & 20 & Construction & $\begin{array}{l}\text { Public and } \\
\text { Private }\end{array}$ \\
\hline $\begin{array}{l}\text { R7 (Quantity } \\
\text { Surveyor) }\end{array}$ & 52 & Masters & 6 & 27 & 27 & Construction & Public \\
\hline \multicolumn{8}{|c|}{ CONTRACTORS } \\
\hline R8 (Director) & 39 & Professional & 15 & 15 & 15 & Construction & $\begin{array}{l}\text { Private \& } \\
\text { Public }\end{array}$ \\
\hline $\begin{array}{l}\text { R9 (CEO \& } \\
\text { Administrator) }\end{array}$ & 55 & $\begin{array}{l}\text { Masters/ } \\
\text { Professional }\end{array}$ & 1 & 32 & 32 & Construction & $\begin{array}{l}\text { Private \& } \\
\text { Public }\end{array}$ \\
\hline $\begin{array}{l}\text { R10(Administrative } \\
\text { Director) }\end{array}$ & 45 & $\mathrm{BA}$ & 7 & 15 & 19 & Construction & $\begin{array}{l}\text { Private \& } \\
\text { Public }\end{array}$ \\
\hline $\begin{array}{l}\text { R11 (Real Estate } \\
\text { Developer) }\end{array}$ & 62 & A-Level & 35 & 35 & 40 & Construction & $\begin{array}{l}\text { Private \& } \\
\text { Public }\end{array}$ \\
\hline \multicolumn{8}{|c|}{ GOVERNMENT OFFICIALS } \\
\hline $\begin{array}{l}\text { R12 (Project } \\
\text { Coordinator) }\end{array}$ & 50 & $\mathrm{BA}$ & 2 & 11 & 27 & Construction & Public \\
\hline R13 (Consultant) & 45 & $\begin{array}{l}\mathrm{BA} / \mathrm{PgD} / \text { Profe } \\
\text { ssional }\end{array}$ & 10 & 17 & 20 & Construction & Public \\
\hline R14 (Consultant) & 60 & $\begin{array}{l}\text { BA/Profession } \\
\text { al }\end{array}$ & 5 & 15 & 40 & Construction & Public \\
\hline $\begin{array}{l}\text { R15 (Physical } \\
\text { Works director) }\end{array}$ & 45 & Diploma & 7 & 12 & 25 & Construction & $\begin{array}{l}\text { Public \& } \\
\text { private }\end{array}$ \\
\hline $\begin{array}{l}\text { R16 (Project } \\
\text { Coordinator) }\end{array}$ & 42 & Diploma & 19 & 10 & 19 & Construction & $\begin{array}{l}\text { Public \& } \\
\text { Private }\end{array}$ \\
\hline
\end{tabular}

